\title{
India approves GM cotton
}

ndia has approved the commercial planting of its first genetically modified (GM) crop-insect-protected hybrids of cotton developed by Monsanto (St. Louis, MO) and its Indian partner Maharashtra Hybrid Company (Mahyco; Jalna, India)—for three years (April 2002-March 2005). The decision has been hailed by industry, which says farmers have been clamoring for GM cotton. But critics and organic farmers want the decision reversed, alleging it was a sell out to multinational companies (MNCs) and is not in the interest of small farmers.

The three cotton hybrids cleared by the Genetic Engineering Approval Committee (GEAC) under the Indian Ministry of Environment and Forests (New Delhi) on February 26 carry the Bacillus thuringiensis (Bt) gene that confers protection against bollworm, a serious cotton pest in India. Although India cultivates the most cotton in the world (nine million hectares), it produces less than China and the United States. "Farmers spend annually 12 billion Rupees (Rs.; $\$ 250$ million) in controlling the bollworms," says T.M. Manjunath, director of the Monsanto Research Center in Bangalore. By backing the use of $\mathrm{Bt}$ cotton, India has signaled to the world that it is encouraging farmers to use biotechnology to raise their competitiveness towards the production levels of China and the US, and the GEAC's decision could throw open the doors for growth of more varieties of GM crops in India and send a powerful signal to fence-sitters in Asia such as Thailand to join the GM race, say industry watchers.

Monsanto plans to sell the GM seeds through its joint venture with Mahyco, which has stocked enough seeds to cover 150,000 hectares this year and has joined up with three more Indian firms to raise the seed production capacity to cover three million hectares next year. At Rs. 1,200/kg, Bt-cotton seeds will be five times costlier than the nonBt variety, but P.K. Ghosh, senior adviser in the Indian Department of Biotechnology (DBT; New Delhi) and member of GEAC, told Nature Biotechnology that a farmer planting Bt cotton can make a profit of Rs. 5,000 (\$120) "after accounting for all the costs" as productivity would double to about $700 \mathrm{~kg}$ per hectare.

However, the government's approval comes with conditions. To prevent or delay development of Bt resistance, farmers have to provide refugia by planting non-Bt cotton in five rows or $20 \%$ of the area, "whichever is higher." Monsanto and Mahyco are to monitor resistance development in bollworms and pollen migration and report to GEAC any cross-pollination with other plants. "We are going to make sure that Mahyco follows these conditions and we will be checking the compliance at the company and dealers levels," GEAC chair A.M. Gokhale said in a press conference.

Small-holdings are common in India, with $65-70 \%$ of cotton farmers holding between 1 and 1.5 hectares, according to the ministry of agriculture. Suman Sahai, a geneticist and convener of nongovernmental organization (NGO) Gene Campaign, wonders whether farmers could afford to leave $20 \%$ of the area for insect refuge. "Given the record of pesticide abuse because of the failure to educate farmers, is it realistic to expect that the complex system of refuges will be implemented even by larger farmers?" she asks.

\section{The Bt cotton is fundamentally at odds with the agricultural and climatic conditions in India.}

However, Ghosh says compliance is not really an issue, admitting that the refugia mandate was included as a condition mainly to pacify NGOs. He says many small cotton farmers will continue to use the local variety, as Bt-hybrids are too demanding in terms of fertlizers and costs. "If you ask me, we expect only $50 \%$ of the farmers to go for Bt cotton, and the other $50 \%$ will act as refugia. It does not really matter if small farmers do not comply."

Channapatna Prakash, director of the Center for Plant Biotechnology Research at Tuskegee University (Tuskegee, AL), is an advocate of GM technology and agrees with Ghosh. "In India, even in the densest cotton growing areas, farmers have not adopted a monoculture cropping pattern. Other crops such as vegetables are always grown along with cotton," he told the Financial Express. "Therefore, less than $100 \%$ compliance is not a big deal. It's only a few years down the line, when the proportion of Bt cotton increases, that this problem can emerge, but by then we should have different varieties of GM cotton, which will help tackle the resistance problem."

Nevertheless, on April 4, some 12 farmers' organizations and a group representing organic farmers demanded that the Indian government reverse GEAC's decision, charging that it was a move "to dislodge small farmers" and a sell out to MNCs.

Devinder Sharma, president of the Forum for Biotechnology and Food Security (New Delhi), says the government succumbed to Monsanto's lobby. "Otherwise tell me why it failed to promote the integrated pest management (IPM) approach recommended by its own scientists?" Two years ago, the National Centre for IPM (New Delhi) carried out a major experiment in 200 hectares of farmers' land in Maharashtra, where it produced $1,000 \mathrm{~kg}$ of cotton per hectare-three times the national average-without the use of pesticides or GM crops. But the government is not following it up on a large scale. "Such technologies will not be promoted simply because there is no industry behind it," says Sharma.

Some, such as K.P. Prabhakaran Nair, agricultural scientist and a senior fellow of the Alexander von Humboldt Foundation (Munich), say Bt cotton will benefit only big farmers who can comply with the refugia mandate and afford the fertilizers. But "nothing can be farther from the truth," argues Gurunurti Natarajan, a US-trained consultant on GM crops and an agricultural advisor. "Bt technology is scale-neutral because the benefit to the farmer is embedded in every seed. Therefore, any farmer that uses this technology would benefit from it just as equally, regardless of the number of acres that he were to plant. This has been amply proved in China where land holdings are small and small farmers have benefited immensely from adopting the Bt technology."

However, Sahai says that Bt cotton, developed for cold countries where the predominant pest is the bollworm, is unlikely to work for more than a few years in hot, tropical India where the pest load is high, because "it is fundamentally at odds with the agricultural and climatic conditions here" and "will quickly become resistant to $\mathrm{Bt}$ toxin and the crop will fail." She points out that the Bt-cotton crop has failed in South Sulawesi, Indonesia, because the pests have become resistant to the Bt toxin. Sahai is concerned that when this happens in India, small farmers who have invested in the GM seeds will be worse off than they were before. Unlike the US farmer who is fully protected by subsidies, says Sahai, "there is nobody to protect Indian farmers should Bt cotton fail." Sahai also notes Monsanto's record of prosecuting farmers for technology infringement and harassing them with lawsuits, and adds that the government is being naïve in entrusting the post-monitoring job to Monsanto.

Summing up, Prakash agrees that the resistance problem is real but says: "You don't stop using a knife just because it gets blunt."

K.S. Jayaraman, New Delhi 